\title{
ANALYSIS OF FINANCIAL SERVICES SECTOR TRANSPARENCY THROUGH WHISTLE BLOWING: THE CASE OF SOUTH AFRICA AND SWITZERLAND
}

\author{
Herbert Kawadza \\ University of the Witwatersrand, Johannesburg, South Africa
}

\begin{abstract}
There intimate connections between the 2007-9 financial crisis, ineffective regulation and the scandals that preceded that calamity, have led to rising demands for the re-evaluation and smarter coordination of the financial sector's governance, supervision and enforcement mechanisms with a view to preventing their recurrences. The calls for changes in the current systems come on the backdrop of the recognition that the financial fiascos cast a shadow over the ability of codes of conduct, traditional supervisory and enforcement strategies to insulate the global financial sector from failure. In essence, demands for a new architecture in the governance of the pilloried sector are embedded in the critical need to re-instil trust and credibility eroded by inter alia, lack of transparency in the sector. Intertwined with human frailties such as, and mainly, untrammelled greed, excessive 'group think' and 'herd behaviour,' widespread intransparency engendered a fertile ground upon which scandals flourished. Post-crisis diagnostics have arguably steam-rolled into a governance discussion in which the need for transparency and the importance of ethical and moral aspects of economic activities within the financial services have come to the fore. This paper contributes to that discussion by building on the widely recognised fact that whistle blowing is an essential element of the transparency agenda and that it is a core element of a well-functioning risk management system' it seeks to make a contribution to the literature on global economic governance and financial transparency. The paper is a comparative examination of the degree to which Switzerland and South Africa have enhanced the transformative role of transparency through whistle blowing. This is a crucial quest especially in view of the fact that the recent financial crisis highlighted how internationalised the financial sector has become and demonstrated how, in the absence of harmonized policies and standards, the perils of systemic risk and cross border contagion can easily spread through the global village's fault lines and vulnerabilities.
\end{abstract}

Research for this paper was funded by the Swiss Secretariat for Economic Affairs (SECO) under a partnership agreement with the World Trade Institute of the University of Bern, Switzerland. 


\section{ANALYSIS OF FINANCIAL SERVICES SECTOR TRANSPARENCY THROUGH WHISTLE BLOWING: THE CASE OF SOUTH AFRICA AND SWITZERLAND}

In view of the intimate connections between the 2007-9 financial crisis, ineffective regulation and the scandals that preceded that calamity, ${ }^{1}$ there have been increasing demands for the reevaluation and smarter coordination of the financial sector's governance, supervision and enforcement mechanisms with a view to preventing their recurrences. ${ }^{2}$ Calls for changes in the current systems come on the backdrop of the recognition that the financial fiascos cast a shadow over the ability of codes of conduct, traditional supervisory and enforcement strategies to insulate the global financial sector from failure. ${ }^{3}$ In essence, demands for a new architecture in the governance of the pilloried sector are embedded in the critical need to re-

\footnotetext{
${ }^{1}$ See generally for a detailed analysis of the role of ineffective enforcement of financial markets regulation and the financial crisis, Majority and Minority Staff Report, Wall Street and the Financial Crisis: Anatomy of a Financial Collapse (Apr. 13, 2011), available at http://www.gpo.gov/fdsys/pkg/CHRG112shrg57323/html/CHRG-112shrg57323.htm (accessed 27 June 2014); KT Jackson "The scandal beneath the financial crisis: Getting a view from a moral-cultural mental model" 33/2 Harvard Journal of Law \& Public Policy (2010) 735; S Deakin "Corporate governance and financial crisis in the long run", available at: <http://www.cbr.cam.ac.uk/pdf/WP417.pdf> (last accessed 27 June 2014); J Winter "The financial crisis: Does good gorporate governance matter and how to achieve it?” Aug 2011 DSF Policy Paper, No. 14, available at: <http://www.dsf.nl/assets/cms/File/Research/DSF\%20Policy\%20Paper\%20No\%2014\%20The\%20Financial\%2 0Crisis $\% 20-$

\%20Does\%20Good\%20Corporate\%20Governance\%20Matter\%20and\%20How\%20to\%20Achieve\%20it\%20A ug\%202011.pdf> (last accessed 27 June 2014).

2 E Avgouleas Governance of Global Financial Markets The Law, the Economics, the Politics, (2012,Cambridge); TCW Lin "The new financial industry" (2014) 65/ 3 Alabama Law Review 567; RB Ahdieh "The visible hand: Coordination functions of the regulatory state" (2010) 95 Minn. L. Rev. 578; C Schwartz "G20 financial regulatory reforms and Australia" (2013) RBA Bulletin 77; M Kawai and E S Prasad Financial Market Regulation and Reforms in Emerging Markets (2011, Brookings Institution Press and Asian Development Bank Institute); E Botha and D Makina "Financial regulation and supervision: Theory and practice in South Africa" (2011) 10/11 International Business \& Economics Research Journal 27; D Alford "Supervisory colleges: The global financial crisis and improving international supervisory coordination" (2010) 24 Emory International Law Review 57.

${ }^{3}$ See S Perks and E E Smith "Employee perceptions regarding whistle blowing in the workplace: A South African perspective" (2008) 6/2 SA Journal of Human Resource Management 15; D Rossouw Organization Ethics in Africa. 2nd Ed., (2002, Cape Town: Oxford University Press); A E Hofmeister "Whistleblowing. A suitable instrument to improve public corporate governance?", available at: <http://www.sgvw.ch/d/Documents/Jahrbuch\%20PDFs/Jahrbuch\%202010/11_hofmeister.pdf> (last accessed 29 June 2014).
} 
instil trust and credibility eroded by inter alia, lack of transparency ${ }^{4}$ in the sector. Intertwined with human frailties such as, and mainly, untrammelled greed, excessive 'group think' and 'herd behaviour,' 5 widespread intransparency engendered a fertile ground upon which scandals flourished. ${ }^{6}$ Essentially therefore, post-crisis diagnostics have arguably steam-rolled into a governance discussion in which the need for transparency and the importance of ethical and moral aspects of economic activities within the financial services have come to the fore. ${ }^{7}$ The understanding is that;

"Financial markets, when left to their own devices, have proven fertile grounds for disastrously bad behavior and poor decision making. Banks take on extreme leverage to fuel speculative and often foolhardy bets involving poorly understood investments; conflicts of interests can skew incentives such that analysts insufficiently assess and report risk; con men can develop fraudulent schemes to cheat investors out of their savings; and executives are empowered to act in their

\footnotetext{
${ }^{4}$ See e.g. M Bouvard, P Chaigneau and A de Motta "Transparency in the financial system: Rollover risk and crises" Financial Markets Group Discussion Paper 700 (February 2012), available at:

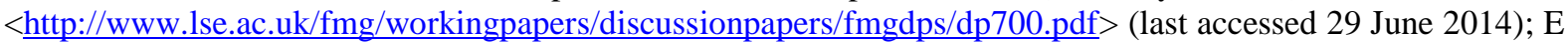
Engelen, I Ertürk, J Froud, S Johal, A Leaver, M Moran, A Nilsson and K Williams After the great complacence: Financial Crisis and the Politics of Reform (2011, Oxford University Press); A Hudson The law of finance, $1^{\text {st }}$ ed. (2009, Sweet and Maxwell) at 846; S Maijoor "Market transparency - does it prevent crisis?" European Securities and Markets Authority FMA Supervision Conference, Vienna, 29 September 2011, available at <http://www.esma.europa.eu/system/files/2011_322.pdf〉 (last accessed 30 June 2014); Transparency International "The role of transparency in financial services reform" Presentation to Group of Experts on Banking Issues (GEBI) Brussels 1 June 2011, available at: $<$ http://www.transparencyinternational.eu/wp-content/uploads/2012/08/2011-07-08GEBI_position_paper_final_080711.pdf> (last accessed 30 June 2014).
}

${ }^{5}$ R M Lastra and G Wood "The crisis of 2007-09: Nature, causes, and reactions" (2010) 13/3 Journal of International Economic Law 531.

${ }^{6}$ T M Dworkin "US whistleblowing: A decade of progress?" in D B Lewis (ed) A Global Approach to Public Interest Disclosure: What Can We Learn from Existing Whistleblowing Legislation and Research? (2010, Edward Elgar Publishing) 36.

${ }^{7}$ See for instance L Rohde "Lessons from the last financial crisis and the future role of institutional investors" (2011) 1 OECD Journal: Financial Market Trends 1; A L Nazareth and M E Tahyar "Transparency and confidentiality in the post financial crisis world-Where to strike the balance?" (2011) 1 Harvard Business Law Review 146; AG Haldane "Rethinking the financial network" (2009), available at: <http://www.bankofengland.co.uk/publications/speeches/2009/speech386.pdf> (last accessed 30 June 2014); G Feuerberg "Greed, lack of transparency caused financial crisis, says Greenberger" Epoch Times, November 6, 2012; Transparency International "Greed, reckless behaviour and the financial crisis: A timeline"18 October 2012 , available at: 〈http://www.transparency.org/news/feature/greed_reckless_behaviour_and_the_financial_crisis_a_timeline> (last accessed 1 July 2014). 
own short-term interest instead of the interests of the firms for which they work and shareholders." 8

On that basis regulators have widely embarked on extensive reformulation of national regulatory approaches and structures in the hope of enhancing financial stability and averting fraudulent activities. ${ }^{9}$

While such legislative interventions cannot be questioned, this note contends that for as long as there is "jurisdictional dissonance ${ }^{10}$ between the regulators and the financial sector, that is to say, for as long as the regulatory agencies are too remote from the firms they supervise; ${ }^{11}$ these legislative paradigms will not avail much. That cynical observation is premised on the notion that unless the substance of those reforms is reinforced by an aggressive culture which engages with inter alia, the insiders who have better and greater

\footnotetext{
${ }^{8} \mathrm{C}$ Brummer Soft Law and Global Financial System: Rule Making in the 21st Century (2012, Cambridge University Press) at 1; R Kuttner Financial Regulation after the Fall 3 Demos Effective Regulation for the 21st Century Report Series, 2009, available at: 〈http://www.demos.org/pubs/reg fall.pdf.> (last accessed 1 July 2014).
}

${ }^{9}$ See for instance A E Hofmeister "Whistleblowing. A suitable instrument to improve public corporate governance?", available

at <http://www.sgvw.ch/d/Documents/Jahrbuch\%20PDFs/Jahrbuch\%202010/11_hofmeister.pdf > (last accessed 2 July 2014).

${ }^{10}$ Lin “The new financial industry” (2014) 65/3 Alabama Law Review 567 at 591.

${ }^{11}$ Prior to the financial crisis, reliance on risk-based regulation entailed use of meta-regulation where firms were given wider discretion to act according to their own interests. The rationale for this approach was an assumption that a 'command-and-control' environment would be counter-productive seeing as firms were better placed and able to recognize those systems and controls that required to be put in place established or adapted. Ultimately this had unintended consequences of making regulators out of touch with financial market issues. A major criticism of enrolling the regulated in the development of policies aimed at meeting the regulators' objectives is that it amounted to a renunciation of the regulatory agencies' enforcement duties. See for instance F Akinbami "Is meta-regulation all it's cracked up to be? The case of UK financial regulation" (2012) Journal of Banking Regulation 1; C McCarthy "Risk-based regulation: the FSA's experience" Speech delivered at ASIC Summer School, $\quad$ Sydney, $13 \quad$ February $2006 . \quad$ Available <http://www.fsa.gov.uk/library/communication/speeches/2006/0213_cm.shtml>; E Avgouleas The Governance of Global Financial Markets: The Law, the Economics, the Politics (2012, Cambridge University Press) pp. xxii+ 476; Commission Staff Working Document "Corporate governance in financial institutions: Lessons to be drawn from the current financial crisis, best practices" (2010). Available at: <http://ec.europa.eu/internal_market/company/docs/modern/sec2010_669_en.pdf> (last accessed 2 July 2014). See also A Johnson "Banking \& finance: Challenges of compliance in Nigeria" (August 2008), available at: $<$ http://www.financialnigeria.com/development/developmentreport_category item detailp.aspx?item=254\&cate goryid=3> (last accessed 2 July 2014); P Tucker "Regulatory reform, stability, and central banking" Hutchins Center on Fiscal and Monetary Policy (January 2014), available at: $<$ http://www.brookings.edu/ /media/research/files/papers/2014/01/16\%20regulatory\%20reform\%20stability\%20central\%20 banking\%20tucker/16\%20regulatory\%20reform\%20stability\%20central\%20banking\%20tucker.pdf> (last accessed 2 July 2014); J Werdigier “U.K. financial oversight is overhauled” New York Times, June 19, 2008. 
access to the operations of the financial sector, such measures will not attain the expected objectives. $^{12}$

\begin{abstract}
"The jurisdictional dissonance between the regulators and the regulated has encouraged financial players to engage in games of regulatory arbitrage within and across nations, by skirting and leaping ahead of existing law, and by moving between shadow finance and regulated finance. The jurisdictional gaps and gulfs among regulators often serve as fertile ground for financial innovation and malfeasance."13
\end{abstract}

Without the active participation of insiders in these intricately formulated corporations, where engrained greed is considered to be "the engine that propels a market economy," seeking to understand what goes on in such organizations would be faced with a substantial challenge. ${ }^{15}$ Compounding that challenge is the fact that exposing financial crime through traditional surveillance and investigative techniques is generally a resource intensive ${ }^{16}$ pursuit and often leads to cases being discontinued or dropped for lack of evidence. ${ }^{17}$

\footnotetext{
12 See generally Hofmeister "Whistleblowing. A suitable instrument to improve public corporate governance?"above at note 9.

${ }^{13}$ Lin "The new financial industry" above at note 10 at 591. See also V Fleischer "Regulatory arbitrage" (2010) 89 Tex. L. Rev. 227; E F Greene and E L Broomfield "Promoting risk mitigation, not migration: A comparative analysis of shadow banking reforms by the FSB, USA and EU" (2013) 8/6) CAP. Mkts. L.J. 14.

${ }^{14}$ Judge Easterbrook in Wilkow v. Forbes, Inc., 241 F.3d 552, 557 (7th Cir. 2001). See also J Bakan The Corporation The Pathological Pursuit of Profit and Power (2005, Free Press).

${ }^{15}$ DV Jernberg Whistle-Blower Programmes: The Counsel-Assisted Option, (2004,Chicago: Illinois); T D Miethe Whistleblowing at Work: Tough Choices in Exposing Fraud, Waste, and Abuse on the Job, (1998, Westview Press); J P Near and M P Miceli "Wrongdoing, whistle-blowing, and retaliation in the U.S. government what have researchers learned from the Merit Systems Protection Board (MSPB) survey results" (2008) 28 Review of Public Personnel Administration 263.
}

${ }^{16}$ See A Carvajal and J Elliott "The challenge of enforcement in securities markets: Mission impossible?", available at: < http://www.imf.org/external/pubs/ft/wp/2009/wp09168.pdf> (last accessed 4 July 2014); Lin, "The new financial industry" above at note 10 at 567; M Maremont and D Solomon "Missed chances: Behind SEC's failings: Caution, tight budget, '90s exuberance' " Wall St. Journal, Dec. 24, 2003; D Leonard 'Outmanned, outgunned, and on a roll', Business Week, April 23, 2012 at 60-66.

${ }^{17}$ See for instance I Carr and D Lewis "Combating corruption through employment law and whistleblower protection” (2010) 39/1 Industrial Law J 52. 
Given the complexities that characterise and impede on most regulatory and supervisory agencies' capacity to effectively execute their mandate, ${ }^{18}$ it is fair to say that reliance on other ex-ante supervisory mechanisms that engender compliance would be expedient in deterring or mitigating the magnitude of the hidden activities and debacles. ${ }^{19}$ On account of the fact that the financial scandals were largely a consequence of greed and lack of ethics, the assumption is that transparency would assist in promoting the interests of an informed market for financial services. ${ }^{20}$ Fostering transparency in the financial sector would not only disclose unfavourable financial assessment thereby assisting the investor in making informed decisions ${ }^{21}$ but also provide an invaluable surveillance tool, a means of protecting investors as well as promoting efficient and fair markets. ${ }^{22}$

This note is a contribution to that subject. By building on the widely recognised fact that whistle blowing is an essential element of the transparency agenda ${ }^{23}$ and that it is a core element of a well-functioning risk management system, ${ }^{24}$ it seeks to make a contribution to the literature on global economic governance and financial transparency. It attempts to accomplish that objective by way of a comparative examination of the degree to which Switzerland and South Africa have enhanced the transformative role of transparency through

\footnotetext{
${ }^{18}$ See generally J G Lambsdorff The Institutional Economics of Corruption and Reform. Theory, Evidence and Policy (2007, Cambridge University Press).

${ }^{19}$ This assertion is premised on the understanding that that financial crime is often accompanied by warning signs that are known to potential 'whistle-blowers' who could alert the relevant authorities to the wrongdoing. See generally L Roberts and M Herring "Understanding the new SEC whistle blower program", available at: <http://www.cooley.com/files/Understanding\%20the\%20New\%20SEC\%20Whistleblower\%20Program.pdf> (last accessed 5 July 2014).
}

${ }^{20}$ A E. Hofmeister "Whistleblowing. A suitable instrument to improve public corporate governance?" above at note 12; P Latimer "Whistleblowing in the financial services sector" (2002) 21 University of Tasmania Law Review 39.The OECD defines transparency as "an environment in which the objectives of policy, its legal, institutional, and economic framework, policy decisions and their rationale, data and information related to monetary and financial policies, and the terms of agencies' accountability, are provided to the public in a comprehensible, accessible, and timely manner." See OECD "Glossary of statistical terms", available at: <http://stats.oecd.org/glossary/detail.asp?ID=4474> (last accessed 7 July 2014).

${ }^{21}$ See generally M A Young Banking Secrecy and Offshore Financial Centres: Money Laundering and Offshore Banking (2013, Routledge) 139; YY Chong Investment Risk Management (2004, John Wiley \& Sons) 54.

${ }^{22}$ See IOSCO 'Objectives and principles of securities regulation” para 4, <available at www.iosco.org.> (last accessed 9 July 2014).

${ }^{23}$ M P Miceli, J P Near and T M Dworkin Whistle-blowing in Organizations, (2008, New York: Routledge) Introduction; M Kaptein "from inaction to external whistleblowing: the influence of the ethical culture of organizations on employee responses to observed wrongdoing” (2011) 98/3/ Journal of Business Ethics 513.

${ }^{24}$ D Stewart Organization Ethics (1996, McGraw-Hill Companies, Inc.,). 
whistle blowing. This is a crucial quest especially in view of the fact that the recent financial crisis highlighted how internationalised the financial sector has become and demonstrated how, in the absence of harmonized policies and standards, the perils of systemic risk and cross border contagion can easily spread through the global village's fault lines and vulnerabilities. ${ }^{25}$ It has been shown that "market participants take advantage of gaps in the financial system; they also take advantage of uncoordinated regulations by engaging in highly profitable and dangerous games of arbitrage and evasion." 26

It is therefore hoped that a comparison of this nature, albeit limited to two jurisdictions, can be a crucial tool in minimising counterpart risk by bringing about some policy coherence through an alignment of standards and norms in the governance of financial sector. ${ }^{27} \mathrm{~A}$ comparison of this nature is also crucial especially having regard to the accepted fact that regulatory and standard convergence across jurisdictions is regarded as a precondition for financial integration. ${ }^{28}$ Likewise, the linkages between South Africa and Switzerland ${ }^{29}$ suggest that they have a a stake in the soundness and stability of each other's

25 See IMF "Understanding financial interconnectedness" (October 4, 2010), available at: <http://www.imf.org/external/np/pp/eng/2010/100410.pdf> (last accessed 9 July 2014); D Z K Árvai and İ Ötker-Robe "Financial interlinkages and financial contagion within Europe" IMF Working Paper WP/09/6 (2009); J Chan-Lau, M Espinosa, K Giesecke and J Solé “Assessing the systemic implications of financial linkages" in IMF Global Financial Stability Rep ort (April 2009). See generally R G Rajan Fault Lines: How Hidden Fractures Still Threaten The World Economy (2010, Princeton University Press); C M Reinhart and K S Rogoff This Time Is Different: Eight Centuries of Financial Folly (2009, Princeton University Press); L A Bebchuk and H Spamann "Regulating bankers” pay" (2010) 98 Geo. L.J. 247.

${ }^{26}$ Lin "The new financial industry" above at note 10 at 606 . See also C K Whitehead "Reframing financial regulation" (2010) B.U. L. Rev. 1.

${ }^{27}$ See for instance S A Beaulier et al. "Knowledge, economics, and coordination: Understanding Hayek's legal theory" (2005) 1 (209) N.Y.U. J.L. \& Liberty 211; J Freeman \& J Rossi 'Agency coordination in shared regulatory space" (2010) 1 Harv. L. Rev. 1131; C K Whitehead "Destructive coordination" (2011) 96 Cornell L. Rev. 323.

${ }^{28}$ C Jordan and G Majnoni "Financial regulatory harmonization and the globalization of finance", available at: <http://wwwwds.worldbank.org/servlet/WDSContentServer/WDSP/IB/2002/11/22/000094946_02110804063983/Rendered/ PDF/multi0page.pdf> (last accessed 11 July 2014).

${ }^{29}$ For instance, over 36.5 billion South African rands are held in the Swiss banking system, see Swiss National Bank "Banks in 2013 report", available at: <http://www.snb.ch/ext/stats/bankench/pdf/deen/Die_Banken_in_der_CH.book.pdf> (last accessed 11 July 2014). Further, according to the Federal Department of Foreign Affairs South Africa is Switzerland's most important trading partner on the African continent see "Bilateral relations between Switzerland and South Africa", available at: $<$ http://www.eda.admin.ch/eda/en/home/reps/afri/vzaf/bilsaf.html $>$ (last accessed 12 July 2014). See also Mission of Federal Councillor J N Schneider-Ammann to South Africa "South Africa and Switzerland: A long-standing friendship" $(4-8$ September 2013), available at: 
financial system. As such the predictability of finance-related standards and frameworks between these countries could be enhanced by a comprehensive understanding and convergence of their governing laws.

Further, the choice of South Africa as a subject of this discussion is based on pragmatic considerations. Of late there have been increased calls for transparency, accountability and good governance in both public and private institutions through especially, the exposure of illicit conduct by individuals. ${ }^{30}$ Switzerland, on the other hand, presents an interesting contrast $^{31}$ owing inter alia, to the controversy surrounding its approach which is steeped in a long history of financial services secrecy. ${ }^{32}$ To start with, not only does Switzerland manage approximately one fourth of total global offshore assets, it has also been depicted as the "old grand-daddy of tax havens." 33 For a long time and until recently, it has managed to fend off international criticism and pressure to dismantle the existing system ${ }^{34}$ and has instead, taken

<http://www.economiesuisse.ch/de/SiteCollectionDocuments/Southafrica_20131006.pdf > (last accessed 11 July 2014); South Africa info "Swiss investment in SA multiplies", (5 September 2013), available at: <http://www.southafrica.info/news/international/switzerland-050913.htm\#.U6m0mLA6mUl> (last accessed 11 July 2014). See also G Kreis Switzerland and South Africa 1948-1994: Final Report of the NFP 42+ Commissioned by the Swiss Federal Council (2007, Peter Lang).

${ }^{30}$ See for instance L Steyn "SA banks worried about costs of economic crime" Mail \& Guardian, 31 Jan 2012; G Hosken "World fraud champs", Times Live, 19 February, 2014; The PwC Global Economic Crime, "Confronting the changing face of economic crime survey", (February 2014), available at: $\langle$ http://www.pwc.co.za/en_ZA/za/assets/pdf/global-economic-crime-survey-2014.pdf > (last accessed 16 July 2014); Business Report "SA companies top fraud survey", (February 19 2014), available at: <http://www.iol.co.za/business/news/sa-companies-top-fraud-survey-1.1649572\#.U6cEjDeKDmI> (last accessed 17 July 2014)

${ }^{31}$ See generally M Giovanoli "Switzerland" in R Cranston (ed) European Banking Law: The Banker-Customer Relationship (1993, Lloyds of London Press, London) 183 at 185.

${ }^{32}$ See for e.g. H B Meier, J E Marthinsen and P A Gantenbein Swiss Finance: Capital Markets, Banking, and the Swiss Value Chain, (2012, John Wiley \& Sons); R Palan, R Murphy and C Chavagneux Tax Havens: How Globalization Really Works (2010, Ithaca NY: Cornell University Press); D Fasnacht Open Innovation in the Financial Services: Growing Through Openness, Flexibility and Customer Integration (2009, Springer); G Stessens Money Laundering: A New International Law Enforcement Model (2000, Cambridge University Press); B N Hanshaw The World Through Our Eyes: A Collaboration of Essays by International Students (2003, iUniverse).

${ }^{33}$ K H Finkelstein The Tax Haven Guide Book ( 1196, Olympia WA: Big Island Media Corp) at 6.

${ }^{34}$ See C H Church, R C Head A Concise History of Switzerland (2013, Cambridge University Press); BFJ

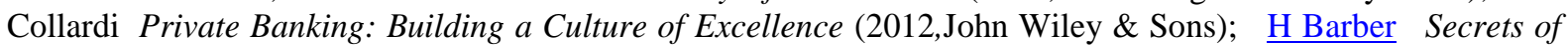
Swiss Banking: An Owner's Manual to Quietly Building a Fortune, (2008, John Wiley \& Sons). For instance, at the G-20 summit in London on April 20, 2009 countries such as the United Kingdom, France, United States and Germany outlined their support for laws aimed at the modification of banking secrecy laws and have since implemented structures that support whistle blowing. In this regard see generally D Erbsen et al. "IRS issues voluntary disclosure guidance for unreported offshore accounts and entities" Tax Update, Mar. 31, 2009, available at: <http://www.dlapiper.com/irs-issuesnew-voluntary-disclosure-guidance-for-unreported-offshore-

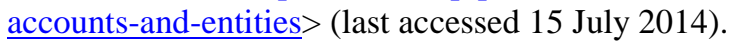


refuge in institutionalised management systems as a means of deterring financial crime. ${ }^{35}$ The tide has now shifted, the globalisation of the financial sector has brought about macroeconomic costs which include loss of national policy making independence, ${ }^{36}$ and hence the urgent need for cohesion between global whistle blowing standards and Swiss mechanisms with a view to creating an integrated system of standards and codes of financial sector good practice.

This note does not purport to be a comprehensive analysis of the various laws that govern disclosure of illegitimate behaviour; rather it seeks to provide an overview of the legislative approaches that govern disclosure of illicit conduct and the extent to which the two countries have sought to attain financial services transparency in the financial sector.

\section{Recounting whistle blowing}

While it lacks definitional exactitude and universal definitional acceptance, ${ }^{37}$ whistle blowing has nonetheless been broadly recognized to entail either, a current or former employee or a contractor of an organisation making a disclosure of perceived illicit or immoral practices of that organisation to authorities who are tasked with taking appropriate action. $^{38}$ It may also emanate through an external source, a channel outside the organisation such as the law enforcement agency or the government. ${ }^{39}$ The motive is generally to avert financial, physical or psychological harm. ${ }^{40}$

\footnotetext{
${ }^{35}$ See A E Hofmeister "Whistleblowing: A suitable instrument to improve public corporate governance?" above at note 12 .

${ }^{36}$ See generally J A Hanson, P Honohan and G Majnoni Globalization and National Financial Systems (2003, World Bank Publications) at 2.

${ }^{37}$ See for instance D Lewis and T Uys "Protecting whistleblowers at work: A comparison of the impact of British and South African legislation" (2007) 49/3 Managerial Law 76; M Kaptein "From inaction to external whistleblowing: The influence of the ethical culture of organizations on employee responses to observed wrongdoing" (2011) 98/3 Journal of Business Ethics 513.
}

${ }^{38}$ J P Near and M P Miceli "Organizational dissidence: The case of whistle-blowing" (1985) 4/1 Journal of Business Ethics 1; P A French Ethics in Government (1993, Englewood Cliffs: Prentice Hall); D Lewis and T Uys "Protecting whistleblowers at work: A comparison of the impact of British and South African legislation" above note 37; P Gottschalk White-Collar Crime: Detection, Prevention and Strategy in Business Enterprises (2010, Universal-Publishers) 104.

${ }^{39}$ S Dasgupta and A Kesharwan "Whistleblowing: A survey of literature" (2010) 9/4 Journal of Corporate Governance 57; M P Miceli, J Pollex Near and T M Dworkin Whistle-Blowing in Organizations ((2013, Psychology Press) Chap 1; T M Dworkin and M S Baucus "Internal vs. external whistleblowers: A comparison of whistleblowing processes" (1998) 17/12 Journal of Business Ethics 1281.

${ }^{40}$ M Davis "Some paradoxes of whistleblowing" (1996) 15/1 Business and Professional Ethics Journal 3. 
Although it is not the purpose of this article to discuss the merits of the concept, it is worth pointing out that, whistleblowing has been accepted a tool for maintaining and enhancing quality of governance and constitutes an essential element of a well-functioning risk management system. ${ }^{41}$ More specifically,

"whistle-blowers play a crucial role in organisational regulatory unit relationships providing otherwise unobtainable information, enhancing the regulatory units' claims to defence of public interest and detracting from any organisation's claims of extreme or biased regulatory activity." ${ }^{42}$

What makes whistle blowing critical are the concerns associated with silence in the face of wrong-doing. This is environment is clearly prejudicial as it results in among other adverse consequences, numbing the consciences of, and discouraging decent individuals from questioning what they clearly consider to be inappropriate conduct. Furthermore, the selfishness and self-interestedness become the norm as employees shift their focus on their own short-term interests and not the mutual interests of the workforce and the organisation. ${ }^{43}$

Likewise, it has been established that the amount of money that organisations have saved and the proportions of potential prejudice that they have been safeguarded from through whistle blowing can never be underestimated. ${ }^{44}$ For instance, a study undertaken in

\footnotetext{
${ }^{41}$ See for instance P Gottschalk White-Collar Crime: Detection, Prevention and Strategy in Business Enterprises (2010, 'Universal-Publishers 104; Lewis and Uys "Protecting whistleblowers at work: A comparison of the impact of British and South African legislation" above at note 38; J S Bowman and DC Menzel Teaching Ethics and Values in Public Administration Programs: Innovations, Strategies, and Issues (1998, SUNY Press) 198.

${ }^{42} \mathrm{D}$ G Bromley "Linking social structure and the exit process in peligious organisations: Defectors, whistleblowers and apostates"(1998) 37/1 Journal for the Scientific Study of Religion 145 at 150; See also for instance Lewis and Uys "Protecting whistleblowers at work: A comparison of the impact of British and South African legislation" above at note 38; M Kaptein "From inaction to external whistleblowing: The influence of the ethical culture of organizations on employee responses to observed wrongdoing" (2011) 98 (3) Journal of Business Ethics 513; J P Near and M P Miceli “Organizational dissidence: The case of whistle-blowing” (1985) 4/1 Journal of Business Ethics 1; P A French Ethics in Government, (1993, Englewood Cliffs: Prentice Hall; $\underline{\mathrm{P}}$ Gottschalk White-Collar Crime: Detection, Prevention and Strategy in Business Enterprises (2010,UniversalPublishers) 104; S Dasgupta and A Kesharwan "Whistleblowing: A survey of literature" above note 39; $\underline{\mathrm{M}}$

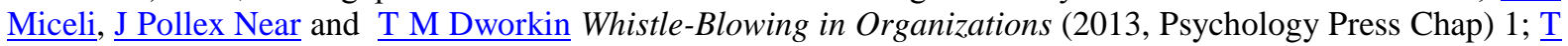
M Dworkin and M S Baucus "Internal vs. external whistleblowers: A comparison of whistleblowing processes" (1998) 17/12 Journal of Business Ethics 1281; M Davis "Some paradoxes of whistleblowing" (1996) 15 (1) Business and Professional Ethics Journal 3.

${ }^{43}$ J P Near and MP Miceli “Whistle-blowing: Myth and reality” (1996) 22/3 Journal of Management 507.

44 National Whistleblower Center "Whistleblowers still the best at detecting fraud", available at: <http://www.whistleblowers.org/index.php?option=com_content\&task=view\&id=102> (last accessed 20 July 2014). See also Price Waterhouse Corporate Crime survey at <http://www.pwc.com/crimesurvey/index.html > (last accessed 20 July 2014).
} 
over 500 European companies demonstrated that such companies suffered prejudice of more than EUR 3.6 billion through fraud ${ }^{45}$ and scholars argue that corporations suffer more fraud occasioned by insiders than by external persons. ${ }^{46}$ The utility of whistle blowing is reinforced further by the fact that acquiring and disclosing corporate insider information improves the functionality of the markets, in that when the markets have the adequate information they are better equipped to allocate resources to the sectors where they are required. ${ }^{47}$ On the contrary, the absence of financial transparency may reverberate into the macroeconomic systems of a country. For instance it could be an effective tool in boosting illicit capital flight from developing countries. ${ }^{48}$ Note should nevertheless be had of the fact that though commendable and popular, tipping about illicit conduct is in some quarters regarded as unethical and condemnable and is symptomatic of lack of loyalty to the organisation. ${ }^{49}$

\section{The legislative mechanisms for whistleblowing in South Africa and Switzerland}

The perception that whistle blowers are unprincipled individuals acts as a powerful vehicle which disincentiizes those who would otherwise want to report corporate wrongdoing. Ordinarily whistle-blowers will only come forward when they have an assurance that their allegations will be investigated and actioned, and that there will be no retaliatory repercussions visited upon them by the individuals whose conduct has been reported. On that backdrop, legislation has been formulated not only to embolden employees to speak out against wrongdoing; but also to safeguard the whistle blowers from retribution. ${ }^{50}$ The ensuing makes an attempt to examine the relevant Swiss and South African legislative framework that both seek to encourage tipping as well as providing protection to those who do so.

\footnotetext{
45 J Zhuang, S Thomas and D L Miller "Examining culture's effect on whistle-blowing and peer reporting" (2005) 44/4 Business \& Society 462.

${ }^{46}$ C Shaw "Fighting fraud: A new European study suggests fraud is wide-spread" CMA Magazine 53, June 2002.

${ }^{47}$ See generally G C Rapp "Beyond protection: Invigorating incentives for Sarbanes-Oxley corporate and securities fraud whistleblowers” (2007) 87 B.U. L. Rev. 91

${ }^{48} \mathrm{Q}$ Reed and A Fontana "Corruption and illicit financial flows. The limits and possibilities of current approaches” (2011) U4 Brief 1.


Malaysian initiative" (2013) 115/2 Journal of Business Ethics 367.

${ }^{50}$ A J Brown (ed.) Whistleblowing in the Australian Public Sector: Enhancing the Theory and Practice of Internal Witness Management in Public Sector Organisations (2008, ANU E Press, Canberra).
} 
The protection of whistle blowing in the South African context hinges on the Protected Disclosures Act 26 of 2000 (hereafter PDA). ${ }^{51}$ Not only does this piece of legislation provide for procedures that a private or public sector employee can follow when making a disclosure regarding improprieties by his or her employer, sections 2 and 3 also shield such employee "from being subjected to an occupational detriment on account of having made a protected disclosure." Equally noteworthy is the fact that this act works retrospectively, protected disclosure extends to issues that occurred before the enactment of the PDA. The protection accorded by this statute is reinforced by remedies that are made available to the employee in the event of any prejudice or occupational detriment triggered by their disclosure. ${ }^{52}$ For

\footnotetext{
${ }^{51}$ It should be noted that this article is confined to the regulation of whistle blowing in the private sector, as such it does not consider other conventions and Acts that regulate whistle blowing in the public sector such as Section 159 of the Companies Act 2008, Reporting of Public Entities Act 93 of 1992, the Corruption Act 94 of 1992, The Public Services Act 103 of 1994 and the Audit Act 122 of 992. In addition, South Africa is a signatory to and has ratified a number of international agreements in which it has agreed to adopt whistle blowing in a bid to fight against corruption and foster accountability and transparency in the management of public affairs and socio-economic development on the continent. These include the African Union Convention on Preventing and Combating Corruption, 2003, the OECD Convention on combating Bribery of Foreign Public Officials in International Business Transactions, as well as the SADC Protocol against Corruption.
}

${ }^{52}$ Section $4(1)$ declares that:

Any employee who has been subjected, is subject or may be subjected, to an occupational detriment in breach of section 3, may-

(a) approach any court having jurisdiction, including the Labour Court.... for appropriate relief; or

(b) pursue any other process allowed or prescribed by any law.

Further, section 4(2) provides that;

(2) For the purposes of the Labour Relations Act, 1995, including the consideration of any matter emanating from this Act by the Labour Court-

(a) any dismissal in breach of section 3 is deemed to be an automatically unfair dismissal as contemplated in section 187 of that Act, and the dispute about

(b) any other occupational detriment in breach of section 3 is deemed to be an unfair labour practice...

Section 4(3) further states that;

(3) Any employee who has made a protected disclosure and who reasonably believes that he or she may be adversely affected on account of having made that disclosure, must, at his or her request and if reasonably possible or practicable, be transferred from the post or position occupied by him or her at the time of the disclosure to another post or position in the same division or another division of his or her employer or, where the person making the disclosure is employed by an organ of state, to another organ of state. 
clarity, section 1 of the PDA defines disclosure to encompass " “.......disclosure of information regarding any conduct of an employer, or an employee of that employer, made by any employee who has reason to believe that the information concerned shows or tends to show one or more of the following:

"(a) That a criminal offence has been committed, is being committed or is likely to be committed;

(b) that a person has failed, is failing or is likely to fail to comply with any legal obligation to which that person is subject;

(c) that a miscarriage of justice has occurred, is occurring or is likely to occur;

(d) that the health or safety of an individual has been, is being or is likely to be endangered;

(e) that the environment has been, is being or is likely to be damaged;

(f) $\ldots . .$.

(g) that any matter referred to in paragraphs (a) to (f) has been, is being or is likely to be deliberately concealed."

Furthermore supplementary protection in the private sector is provided under other pieces of legislation that govern economic activities. For instance, the Investigation into Serious Economic Act 117 of 1991 through which the public intervention can report suspected economic offences to the Investigating Directorate: Serious Economic Offences. Intrinsically connected to the whistleblowing framework are values embedded in the Constitution, particularly section 16 of the Constitution of South Africa which provides for freedom of expression, the right to receive and impart information and ideas. These are said to be related to the constitutional objective of creating transparent and accountable South African society. ${ }^{53}$ In addition to that framework, private organisations such Whistle Blowers - Independent Whistleblowing Service Whistle Blowers (Pty) Ltd , an independent company

And according to section 4(4)

The terms and conditions of employment of a person transferred in terms of subsection (2) may not, without his or her written consent, be less favourable than the terms and conditions applicable to him or her immediately before his or her transfer.

53 See generally P Martin "The status of whistleblowing in South Africa: Taking stock", available at <http://www.advocacyaid.com/images/stories/rrdownloads/ODAC Whistleblowing_Report.pdf > (last accessed 22 July 2014); G Dehn and R Calland Whistleblowing Around the World: Law, Culture \& Practice, Public Concern at Work (2004). 
that provides an alternative channel through which employees may anonymously make reports on fraud and other allegations of impropriety in the workplace. ${ }^{54}$

By contrast, Switzerland boasts of no such elaborate settings governing whistleblowing or protecting whistleblowers. Instead, any semblance of whistle blowing is couched in very broad and vague corporate governance rules whose overall import is a requirement that the board of directors takes appropriate measures to ensure the organisation's compliance with the law, ${ }^{55}$ without specifically calling for a whistleblowing or whistle blower protection scheme. ${ }^{56}$

Under Article 321a of the Code of Obligations employees are obliged to protect their employer's legitimate interests. This common obligation automatically requires an employee to observe business secrets and the prohibition is not extinguished by the termination of employment. As such, employees are bound by specific confidentiality covenants which hinder them from disclosing confidential organisational information. ${ }^{57}$ What is classified as confidential information is not defined by either the labour laws or the Code of Obligation and it up to the courts to determine whether or not the information in issue could be regarded as protected. However, such information has been regarded as that which is

"(i) is known only to a limited group of persons, (ii) is not publicly available and cannot be retrieved by general research, (iii) with regard to which the employer has a legitimate interest in keeping it confidential and (iv) with regard to which a third party can easily recognize that the employer wants to keep it confidential." ${ }^{58}$

\footnotetext{
${ }^{54}$ For more information visit Whistle Blowers at <http://www.whistleblowing.co.za/>

${ }^{55}$ See for instance Swiss Code of Obligations, art 716(2), Article 717(1) of the Code of Obligations. For a discussion of duties see D Campbell and C Campbell International Liability Of Corporate Directors $2^{\text {nd }}$ ed (2013,Juris Publications ); A M Garbarski, La responsabilité civile et pénale des organes dirigeants de sociétés anonymes (2006, Schulthess Juristische Media Juridiques SA Geneve, Zurich, B\&le) 135.

56 See generally "Whistleblowing systems under data protection law", available at: $<$ http://www.homburger.ch/fileadmin/publications/WSDAPROL_01.pdf > (last accessed 23 July 2014).

${ }^{57}$ See WL Keller and T J Darby International Labor and Employment Laws, Volume IIA J. $3^{\text {rd }}$ ed. (2008, Darby).

58 U Sommer and W Wyss "Switzerland" at 42-8, available at: $<$ http://www.walderwyss.com/publications/973.pdf> (last accessed 24 July 2014).
} 
This implied duty to silence strikingly differs from the South Africa's PDA in that under the PDA any contract that specifies that the employee will not disclose illegal or incorrect acts or information would be void.

Within the financial sector specifically, Article 47 of the Banking Act and Article 273 of the Penal Code form the foundation upon which customer confidentiality is premised. ${ }^{59}$ Such protection of secrecy is supplemented by that which exists under the Swiss Constitution, the Swiss Civil Code and the Swiss Code of Obligations. ${ }^{60}$ More particularly, Article 47 of the Swiss Banking Act provides an appropriate demonstration of how any possibility of whistle blowing is likely to be supressed. It creates a criminal penal regime which forbids bank officers such as employees and agents from violating the professional relationship of confidence between bankers and clients. ${ }^{61}$ More specifically Article 47 states that;

\begin{abstract}
"Whoever discloses a secret which has been confided to him or of which he has become aware in his capacity as a member of a governing body, employee, agent, liquidator or commissioners of a bank, as a banking Commission supervisor, as a member of a governing body or employee of recognized auditors, or whoever attempts to induce such a breach of professional secrecy, shall be liable to a term of imprisonment or a fine..."
\end{abstract}

Related to the proscription against disclosure of bank secrecy is Article 43 SESTA which criminalises breach of stock market secrecy. Same provides that;

\footnotetext{
${ }^{59}$ P C Honegger "Swiss banking secrecy" (1990) Butterworths Journal of International Banking and Financial Law 334; M Bauen and N Rouiller Swiss banking: An Introduction for Bank Customers and their Advisors (2013, Schulthess Juristische Medien AG); B Guldimann Inside Swiss Banking (2010, Beat Guldimann ).

${ }^{60}$ See M Moser "Switzerland: New exceptions to bank secrecy laws aimed at money laundering and organized crime" (1995) 27 Case W. Res. J. Int'l L. 324.

${ }^{61}$ An apt illustration of the ambit of Article 47 is made by the conviction of Rudolf Elmer, a Swiss exbanker for giving data to WikiLeaks. See "Swiss ex-banker charged with giving data to WikiLeaks", available at: <http://www.france24.com/en/20110119-whistleblower-swiss-banker-arrested-newcharges-after-sentencing-elmer-wikileaks/\#./?\&_suid=140775600394401884355464697095> (last accessed 23 July 2014). Further, see "Swiss bank secrecy. A whistleblower's woes" The Economist July 19 th 2014.

See also "A major scandal brews after Spain arrests HSBC whistleblower Falciani", available at: http://www.mediapart.fr/journal/international/240712/major-scandal-brews-after-spain-arrests-hsbcwhistleblower-falciani (last accessed 23 July 2014).
} 
"Whoever

(a) discloses a secret which has been confided to him in his capacity as a member of a governing body, employee, agent, liquidator of a stock exchange or a securities dealer, or as a member of a governing body or employee of recognized auditors, or which he has become aware in his official capacity, or

(b) attempts to induce such a breach of professional secrecy shall be liable to imprisonment or a fine"

The proscription captures both intentional and negligent disclosures of a customer's financial information ${ }^{62}$ and because it is an ex officio offense, the Swiss government can prosecute violations of banking confidentiality at its instance without the injured party having filed a complaint. ${ }^{63}$ The import of Article 47 is therefore to "punish disclosures that occur due to a lack of appreciation of the notion of secrecy" ${ }^{\prime 64}$ and serves to protect such secrecy from all forms of intrusion. ${ }^{65}$

Likewise, any disclosure of confidential information could trigger liability under Article 273 of the Swiss Penal Code. By virtue of the fact that banking information fits into the category of business secrets ${ }^{66}$ its disclosure to a private or official foreign organization or its agents amounts to a criminal offence ${ }^{67}$ that attracts a fine or imprisonment of up to three years or $2500^{\prime} 000 \mathrm{CHF} .{ }^{68}$ Furthermore and as if there were not enough to dash all hope whistle

${ }^{62}$ Loi sur les banques [LB] [Banking Act] Nov. 8, 1934, RS 952.0, art. 47 (Switz.); P Nobel Swiss Financial Law in the International Context (2002, Stämpfli); P Nobel Swiss Financial Law and International Standards (2002, Kluwer Law Intl.).

${ }^{63}$ See L Krauskopf “Comments on Switzerland's insider trading, money laundering, and banking secrecy laws" (1991) 9 Int'l Tax \& Bus. Law 277.

${ }^{64}$ P. S. Grassi and D Calvarese "The duty of confidentiality of banks in Switzerland: Where it stands and where it goes. Recent developments and experience the Swiss assistance to, and cooperation with the Italian authorities in the investigation of corruption among civil servants in Italy (the "clean hands" investigation): How much is too much?” (1995) 7 Pace Int'l L. Rev. 329 at 340.

${ }^{65}$ L Krauskopf “Comments on Switzerland's insider trading, money laundering, and banking secrecy laws" (1991) 9 Int'l Tax \& Bus. Law 277.

${ }^{66}$ The Swiss Federal Supreme Court has interpreted business secret as encompassing "any data of economic life, provided there is a legitimate interest in keeping the secret . . . [and] the term may also include relations and transactions of private economy concerning property and income": Krauskopf "Comments on Switzerland's insider trading, money laundering, and banking secrecy laws" ibid at 293.

${ }^{67}$ Code pénal suisse [CP] [Criminal Code] Dec. 21, 1937, RS 311.0, art. 273 (Switz.).

${ }^{68}$ Code pénal suisse [CP] [Criminal Code] Dec. 21, 1937, RS 311.0, art. 273 (Switz.). 
blowing, Article 162 of the Swiss Penal Code safeguards private information from being divulged by those who are legally or contractually obliged to sustain its confidentiality ${ }^{69}$ Captured in this category, as with Article 273, are bankers but with the only difference being that Article 162 is aimed at protecting the interests of private parties. ${ }^{70}$

Contrary to the strict Swiss proscription on disclosure, the South African common law, while recognising traditional bank-customer confidentiality ${ }^{71}$ and whose violation amounts to breach of an implied contractual obligation, ${ }^{72}$ nonetheless provides for limited circumstances where whistleblowing can be an exception to the common law duty of secrecy. South African law allow for the disregard of confidentiality if the interests of the

\footnotetext{
${ }^{69}$ U M Lauchli 'Swiss bank secrecy with comparative aspects to the American approach" (1998) 42 St. Louis U. L.J. 865.

${ }^{70}$ See for instance Alfadda v. Fenn, 149 F.R.D. 28,32 (S.D.N.Y. 1993). It should be noted that the party who owns information in the bank's custody has a right to waive their right to privacy and allow disclosure. It is not the financial institution but the customer who owns the secret only the injured party can bring about an actions for the violation of Article 162. See generally L Krauskopf "Comments on Switzerland's insider trading, money laundering, and banking secrecy laws" above at note 65; L Frei "Swiss secrecy laws and obtaining evidence from Switzerland in Am. Bar Ass'n Nat'l inst. (Ed). Transnational Litigation: Practical Approaches to Conflicts and Accommodations (1984) 14-15.
}

${ }^{71}$ This implied duty of the banker-customer contract is equally protected under certain statutes within the financial sector in South Africa. See for instance, Section 33 (1) (a) 83 of the South African Reserve Bank Act No. 90 of 1989 which inter alia prohibits disclosure of information regarding the affairs of the bank, shareholders or customer unless compelled by law. Further, section of the Constitution of the republic of South Africa provides for the right to personal privacy. Likewise, the Protection of Personal Information Act No 4 of 2013 promotes the protection of personal information being processed by public and private institutions such as banks by placing a number of restrictions, conditions and safeguards relating to such information's use. In terms of section 8 of the Inspection of Financial Institutions Act - an inspector carrying out an inspection of a bank is obliged to preserve confidentiality unless the court, the law or the nature of an inspection compels disclosure. Liability in the case of banker-customer will be based on breach of contract see for instance Legogote Development Co (Pty) v Delta Trust and Finance Co (1970) 1 SA 584; Firstrand Bank Ltd v Chaucer Publications (Pty) Ltd 2008 (2) SA 592 (C); Cambanis Buildings (Pty) Ltd v Gal 1983 (2) SA 128 (N) 137F ;Kearney NO v Standard Bank of South Africa Ltd 1961 (2) SA 647 (T) 650.

${ }^{72}$ This was reiterated in Abrahams v Burns 1914 CPD 452; GS George Consultants \& Investments (Pty) Ltd and others v Datasys (Pty) Ltd 1988 (3) SA 726 (W); Firstrand Bank Ltd v Chaucer Publications (Pty) Ltd 2008 (2) SA 592 (C). See also Stevens and Others v Investec Bank Ltd and Others (2012/32900) [2012] ZAGPJHC 226 (25 October 2012); Tournier v National Provincial \& Union Bank of England [1924] 1 KB 461. See A B Fourie The Banker and the Law (1993, Institute of Bankers in South Africa); A Hudson The Law of Finance 1st ed., (2009, Sweet and Maxwell); J Neethling Neethling's Law of Personality $2^{\text {nd }}$ ed.(2005, Butterworths Durban); EP Ellinger, E Lomnicka and RJA Hooley Ellinger's Modern Banking Law 5th ed. (2011,Oxford University Press ); N T Masete "The challenges in safeguarding financial privacy in South Africa" (2012) 7 (3) Journal of International Commercial Law and Technology 248; R Cranston Principles of Banking Law, 2nd ed. (2003,Oxford: Oxford University Press); HM Schooner and M Taylor Global Bank Begulation: Principles and Policies (2010, Burlington, MA: Academic Press). 
state are treated to be of greater importance than that of a customer's confidentiality. ${ }^{73}$ It may also be varied where such disclosure is in the interest of the bank. It may also supersede client confidentiality where there is a duty to the public to disclose ${ }^{74}$ or if client consents to such disclosure.

\section{Whistleblowing culture in Switzerland and South Africa}

What emerges from the above is that under Swiss law there is no specific statutory protection for whistle blowers in the financial sector. In an unfavourable environment which boasts of far-reaching confidentiality obligations and barriers, employees who report cases of malpractice within a company to the public are treated with cynicism and arguably do so at their own risk. Worse still, "[p]oliticians continue to be very reluctant to discuss the topic, and it is certainly not at the top of any agenda. Recent developments in other OECD countries and the recommendations of international organizations seem to have had no effect on decision makers in Switzerland." ${ }^{75}$ Besides the dominance of labour laws that demand loyalty, equally disconcerting is the fact that cultural hurdles engender fear of reprisals which militates against any likelihood of whistle blowing. ${ }^{76}$ The general societal attitude is that Swiss law serves to protect an individual's right to privacy and that this embraces both economic as well as purely personal affairs. ${ }^{77}$ The rationale is that banking secrecy is the client's secrecy, not the bank's. ${ }^{78}$

Comparatively, this deeply entrenched culture distinguishes Swiss financial sector from other jurisdictions. In fact, “[n]o other country has shown such strong attachment to a

\footnotetext{
${ }^{73}$ See Firstrand Bank Ltd v Chaucer Publications (Pty) Ltd 2008 (2) SA 592 (C).

${ }^{74}$ ibid

${ }^{75}$ A E Hofmeister "Whistleblowing. A suitable instrument to improve public corporate governance?" above at note 12 at 118 .

${ }^{76}$ W H Diamond Switzerland: Tax Exemptions and Reductions in Tax Havens of the World (2010, Matthew Bender).

${ }^{77}$ See Krauskopf "Comments on Switzerland's insider trading, money laundering, and banking secrecy laws" above at note 65; E M Victorson "United States v. UBS Ag: Has the United States successfully cracked the vault to Swiss Banking Secrecy?” (2011) 19 Cardozo J. Of Int'l \& Comp. Law 815.

${ }^{78}$ P Nobel Swiss Financial Law in the International Context (2002, Stämpfli); L Krauskopf "Comments on Switzerland's insider trading, money laundering, and banking secrecy laws" above at note 65. Note however that in case of a suit between the bank and customer the bank would be absolved from such secrecy requirement, see for instance P Nobel Swiss Financial Law and International Standards (2002,Kluwer Law Intl.) at 891.
} 
principle that has enjoyed little public sympathy but strong private support."79 The common rationalisation for this refusal to make concessions with international pressure is that because in Swiss law, financial services officers and employee, like lawyers, priests and doctors owe fiduciary duties to their customers, they must never disclose clients' information that they come across in the performance of their duties.80 It is therefore clear that the Swiss attempts at whistle blowing are moderated by and play second fiddle to the well-developed individual liberties especially those pertaining to the right of confidentiality. It is this attitude that has sustained Swiss' image as an impenetrable fortress against the disclosure of information which disturbingly, has worked against the development of a whistle blowing culture.

Be that as it may, there have been notable developments which seem to suggest that there could be some cracks in the Swiss financial secrecy vault. ${ }^{81}$ This trend is mainly demonstrated by recent cases in which Switzerland has succumbed to international pressure ${ }^{82}$ and against its long-standing tradition of banking secrecy, co-operated with the USA by

\footnotetext{
${ }^{79}$ P S Grassi and D Calvarese "The duty of confidentiality of banks in Switzerland: Where it stands and where it goes. Recent developments and experience the Swiss assistance to, and cooperation with the Italian authorities in the investigation of corruption among civil servants in Italy (the "clean hands" investigation): How much is too much?" (1995) 7 Pace Int'l L. Rev. 329 at 331.
}

${ }^{80}$ H J Bar The Banking System Of Switzerland $5^{\text {th }}$ ed, (1975, Zurich, Schulthess Polygraphischer Verlag); T A Sage "Between a rock and a hard place: The legal and moral juxtaposition of Switzerland's bank secrecy laws as illustrated by the revelation of Nazi-Era accounts" (1997) 21/1 Houston Journal of International Law 117; Art. 321: Violation of Professional Secrecy states that "Clergymen, lawyers, defence counsels, notaries, auditors bound to professional secrecy by the [Swiss] Code of Obligations, physicians, dentists, pharmacists, midwives, and their auxiliaries who divulge a secret entrusted to them or of which they have become aware during the exercise of their profession, shall upon petition, be punished by imprisonment or by a fine..."

${ }^{81}$ It should also be noted that the operation of these stringent banking and stock market secrecy laws is overridden by the obligation to the obligation to testify and make disclosure in terms of cantonal or federal laws.See Article 47 par 4 and article 43 par 3 of SESTA for instance. See also P Nobel Swiss Financial Law and International Standards, (2002, Kluwer Law Intl.).

${ }^{81}$ See Krauskopf “Comments on Switzerland's insider trading, money laundering, and banking secrecy laws" above at 65 .

${ }^{82}$ See for instance M Crutsinger "U.S., Switzerland agree to crack down on tax evaders" USA TODAY, June 20, 2009, available at: <http://www.usatoday.com/money/perfi/taxes/2009-06-19-us-switzerlandtaxtreaty N.htm> (last accessed 29 July 2014). Furthermore after decades of repelling international pressure, Switzerland was has been forced to significantly soften its banking secrecy laws. Bilateral concessions arose mainly from collective pressure exerted by fellow OECD members (risk of blacklisting) as well as in response to U.S. threats to indict UBS, Switzerland's biggest bank. That however is mainly in tax-related issues but these concessions nonetheless point to the development of a new global standard build around transparency. See generally I. Grinberg, "The Battle over Taxing Offshore Accounts" (2012) 304 UCLA Law Review 305; N Z Zeitung "Schritt für Schritt zum gläsernen Bankkunden" June 25, 2013; Handelszeitung "Jedes Nein hat seinen Prei" August, 6, 2012. Further, in 2009 Switzerland agreed to be bound by Article 26 of the OECD Model Tax Convention into its bilateral tax treaties where it is expected to change information to other members on tax evasion and other related issues. 
handing over details of Americans whose assets are held in Swiss banks. ${ }^{83}$ That exceptional case of piercing the banks secrecy should not be enough to cause celebration as that incidence has profound implications on Swiss domestic law sovereignty as well as the nation's strongly guarded culture of financial sector privacy. ${ }^{84}$ The far-reaching effects of this and the continued umbrage at the enforced whistle blowing and this sovereignty-based reluctance to disclose information is best summarised by then Swiss Foreign Minister Micheline CalmyRey who reiterated the fact that the Swiss unwillingness to disclosure of financial information even in cases where foreign account-holders had violated laws of their country "... is about Switzerland's sovereignty. We want our laws to be respected. It is also about our financial centers and about jobs. ${ }^{, 85}$ Likewise, the then Finance Minister that reaffirmed Swiss banking secrecy and warned detractors that it would remain "a nut too hard to crack." ${ }^{, 86}$ It follows therefore that in as far as the Swiss are concerned, any changes to the banking secrecy policies that are introduced, especially in response to international pressure, should be seen in the light of preventing abuse of banking secrecy and not eliminating the "professional" secrecy obligation on the part of the financial sector operatives. ${ }^{87}$

For a country with a statute that specifically targets whistle blowing and one that boasts of an array of institutional features that are necessary to minimise corruption, particularly its constitution, an independent judiciary and a robust and proactive media all which arguably compare favourably compare with those of its more economically advanced counterparts in

\footnotetext{
${ }^{83}$ See U.S. V. UBS AG, No. 09-20423-CIV-GOLD/MCALILEY (S.D. Fla. July 9, 2009; M Crutsinger "U.S., Switzerland agree to crack down on tax evaders" USA TODAY, June 20, 2009, available at: 〈http://www.usatoday.com/money/perfi/taxes/2009-06-19-us-switzerlandtax-treaty N.htm> (last accessed 1 August 2014). See also S A Stark Hidden Treuhand: How Corporations and Individuals Hide Assets and Money (2009,Universal-Publishers).

${ }^{84}$ See B G Cantley "The UBS Case: The U.S. attack on Swiss banking sovereignty" (2011) 7 International Law \& Management Review 1; Brief for Government of Switzerland as Amici Curiae Supporting Respondents at 1 , United States v. UBS AG, No. 109CV20423, 2009 WL 1612394 (S.D. Fla. Apr. 30, 2009).

${ }^{85}$ See J Manley "Swiss minister to meet Clinton ahead of UBS Deadline" Reuter (July 20, 2009). available at: <http://blogs.reuters.com/financial-regulatory-forum/2009/07/20/swiss-minister-to-meet-clinton-ahead-of-ubsdeadline/> ; K McCoy Justice Dep't, UBS Close to Deal on Swiss Tax Secrecy, USA TODAY (July 31,2009), <available at <http://www.usatoday.com/money/perfi/taxes/2009-07-31-UBS-taxevasion_N.html> (last accessed 1 August 2014)

${ }^{86}$ Spiegel Online “Am Bankgeheimnis werdet Ihr Euch die Zähne ausbeißen” March 19, 2008.

${ }^{87}$ See generally M Aubert "The limits of Swiss banking secrecy under domestic and international law" (1984) 2 Int'l Tax \& Bus. Law 273.
} 
the $\mathrm{G} 20^{88}$ South Africa is expected to fare better. The irony however, is that taking into account such resources South Africa does not seem to have succeeded in curbing the existence of fraud or to encourage whistleblowing. ${ }^{89}$ The regime is still best with problems; its regulation is said to be incomplete, a state of flux and there are inconsistencies relating its application and is riddled with gaps and concerns regarding its policy and implementation. ${ }^{90}$ It has been established that,

\begin{abstract}
"The result, at a glance, is a splintered, but interrelated body of laws cutting across different departments and disciplines that are applied erratically by public and private organisations in a manner that has left whistleblowers, at risk of "victimisation, losing their job or damaging their career." ${ }^{.91}$
\end{abstract}

An interplay of cultural, political and historical factors can be said to constitute a barrier that shape people's attitude towards disclosure of wrong doing in organisations. Scholars have shown that within South Africa, whistle blowing is inhibited by the need for loyalty and fear of reprisals. Historically, prior to independence informants who disclosed any information to the apartheid government against the liberation cause were reviled and labelled as impimpi or sell outs. That mind-set is arguably a part of the cultures, that whistle blowing of organisational impropriety amounts to selling out and is treachery which society frowns on. ${ }^{92}$

88 Transparency International "South Africa: A mandate to tackle corruption" (2014), available at: <http://www.transparency.org/news/feature/south_africa_a_mandate to tackle_corruption> (last accessed 1 August 2014).

${ }^{89}$ L Steyn "SA banks worried about costs of economic crime" Mail \& Guardian, 31 Jan 2012; G Hosken "World Fraud Champs" Times Live, 19 February, 2014; The PwC Global Economic Crime "Confronting the changing face of economic crime survey" (February 2014), available at: <http://www.pwc.co.za/en_ZA/za/assets/pdf/global-economic-crime-survey-2014.pdf> (last accessed 1 August 2014); Business Report "SA companies top fraud survey" (February 19 2014), available at : <http://www.iol.co.za/business/news/sa-companies-top-fraud-survey-1.1649572\#.U6cEjDeKDmI> (last accessed 3 August 2014).

90 P Martin "the status of whistleblowing in South Africa: Taking stock", available at: 〈http://www.advocacyaid.com/images/stories/rrdownloads/ODAC_Whistleblowing_Report.pdf > (last accessed 3 August 2014).

${ }^{91}$ Ibid at 19. See also G Dehn and R Calland Whistleblowing around the World: Law, Culture \& Practice, (2004, Public Concern at Work).

${ }^{92}$ See e.g. W Vandekerckhove Whistleblowing and Organizational Social Responsibility: A Global Assessment, (2012, Gower Publishing, Ltd.) M Arszulowicz and WW Gasparski Whistleblowing: In Defense of Proper Action (2011,Transaction Publishers); Parliamentary Monitoring Group "National anti-corruption summit, and public service restructuring: Briefings" (2005), available at: < http://www.pmg.org.za/minutes/20050524national-anti-corruption-summit-and-public-service-restructuring-briefings $>$ (last accessed 7 August 2014). 
Additional impediments include lack of awareness of the protections accorded by the law. On the other hand, where such law is known, the perception that the law does not have the capacity to protect whistle blowers and hence disclosing information is a futile exercise as no action is likely to be taken to remedy the misconduct reported tend to militate against willingness to make disclosure. ${ }^{93}$ Probably the greatest impediment is the lack of incentives to foster a culture of disclosure. So important is incentivising whistleblowing that it has been argued that part of the corporate governance related flaws linked to recent financial crisis was the regulators' underestimation of the utility of financial incentives in corporate whistleblowing. ${ }^{94}$ Coming forward with information is associated with adverse consequences $^{95}$ and unless the rewards of making a disclosure outweigh the risks, individuals are bound to remain quiet.

A further concern has been said to be the PDA's failure to incorporate provision that require organisations to implement robust whistle blowing structures as part of their risk management culture. The protection afforded to disclosers of information by the regulatory framework has also been criticised for being inadequate and poor. Flaws are said to include the fact that it does not amount to an effective deterrent against employers who are intent on victimising the disclosing employee. ${ }^{96}$ In the same manner, the scope of the framework is said to too narrow as protected disclosure is restricted to public and private sector employees to the exclusion of consultants, part-time and agency workers ${ }^{97}$ and citizens who are in no

93 P Martin "The status of whistleblowing in South Africa: Taking stock", available at: 〈http://www.advocacyaid.com/images/stories/rrdownloads/ODAC_Whistleblowing_Report.pdf $>$ (last accessed 8 August 2014).

${ }^{94}$ See generally M A Vega "Beyond incentives: Making corporate whistleblowing moral in the new era of Dodd-Frank Act "Bounty Hunting"' (2012) 45/2 Connecticut Law Review 481; M H Baer "Governing corporate compliance" (2009) 50 B.C. L. Rev. 949; T M Arnold "It's déjà vu all over again: Using bounty hunters to leverage gatekeeper duties” (2010) 45 Tulsa L. Rev. 419; P H Bucy “ 'Carrots and sticks': Post-Enron regulatory initiatives" (2004) 8 Buff. Crim.L. Rev. 318-22; L A Cunningham "Beyond liability: rewarding effective gatekeepers" (2007) 92 Minnesota Law Review 323.

${ }^{95}$ G C Rapp "Beyond protection: Invigorating incentives for Sarbanes-Oxley corporate and securities fraud whistleblowers" (2007) 87 Boston University Law Review 91

${ }^{96}$ See D Lewis and T Uys "Protecting whistleblowers at work: A comparison of the impact of British and South African legislation" (2007) 49 (3) Managerial Law 76; D Culp "Whistleblowers: Corporate anarchists or heroes? Towards a judicial perspective" (1995) 13 Hofstra Lab. \& Emp. L.J. 109.

\footnotetext{
${ }^{97}$ Note however that the time of writing this note, there are growing calls for the review of these parameters and especially the exclusion of contract and agency employees as well as the extension of protection against civil suits to whistle blowers. Additional amendments being proposed include stiffer penalties of up to years and fines for malicious disclosure of false information. See for example Public Protector South Africa "Public
} 
way connected to the organisation. ${ }^{98}$ Not only does the PDA fail to provide incentives to whistle blowers, it also does not offer immunity against civil and criminal liability for making a protected disclosure. Such gaps in the South Africa regulatory provisions have undoubtedly worked against the legitimate intentions and objectives of the legislature and hence the need to for an evaluation of the regime with a view to making it robust. ${ }^{99}$

What stands out from the above discussion is the fact South Africa and Switzerland have adopted widely divergent approaches in regulating disclosure of illegalities in the financial sector. What is reassuring in the case of South Africa and by contrast to Switzerland, is the fact that despite such flaws in the framework, South Africa has managed to build not only a relatively coherent system of disclosure but also a corpus of whistle blowing cases that can be used as a reference. ${ }^{100}$ It is therefore clear that while it is a more mature economy with a long history in regulating its financial sector, when all factors are aggregated, the Swiss approach regulating whistle blowing in line with current global standards lags behind South Africa. This disparity however, is an apt demonstration of the common perspectives that influence the adoption of a disclosure regime; more specifically these two regimes evince the fact that subject to the preferred perception, "whistleblowing is either being considered an ethical and commendable or an unethical and condemnable behaviour. Thereby, the difference in perception is not driven by the stage of development of a given country, but rather by the political and social system."101 Switzerland could build on the experience and examples of its fellow G-20's financial services and broaden the existing

Protector welcomes whistle blower protection law amendments" (01 April 2014), available at: <http://www.pprotect.org/media_gallery/2014/01042014.asp> (last accessed 8 August 2014).

${ }^{98}$ See for instance Second National Anti-Corruption Summit "Roundtable discussion: The Protected Disclosures Act, 2000 (Act No.26 Of 2000)", available at: <http://www.nacf.org.za/anti-corruptionsummits/second_summit/section6_psc_report_summit2_2005.pdf> (last accessed 9 August 2014).

\footnotetext{
${ }^{99}$ For a more comprehensive discussion of the weaknesses associated with the PDA see stakeholder comments made by the Second National Anti-Corruption Summit "Roundtable discussion: The Protected Disclosures Act, 2000 (Act No.26 Of 2000)" ibid.
}

\footnotetext{
${ }^{100}$ There has been a comparatively large corpus of decided cases on whistle blowing, see for instance Ngobeni $v$ Minister of Communications and Another J08/14 [2014] ZALCJHB 96; Communication Workers Union v Mobile Telephone Networks (Pty) Ltd (2003) 24 ILJ 1670 (LC); Tshishonga v Minister of Justice and Constitutional Development and Anot (JS898/04) [2006] ZALC 104 (26 December 2006); Young v Coega Development Corporation (Pty) Ltd [2009] 6 BLLR 597 (ECP) High Court; City of Tshwane Metropolitan Municipality v Engineering Council of South Africa and another (532/08) [2009] ZASCA 151 (27 November 2009). See also CJ Auriacombe "Whistle blowing and the law in South Africa" (2005) 24 (2) Politeia 197.

${ }^{101}$ A E Hofmeister "Whistleblowing: A suitable instrument to improve public corporate governance?" above at note 12 at 117 .
} 
restricted operation of the whistle blower legislation. Unless Switzerland complies and brings its whistle blowing approach in line with its regional counterparts, when it comes to the minimisation of financial services misconduct, unfortunately "...Europe could continue to be a place of diverse policy-making, yet with a common ground."

\section{Conclusion}

That there is need for consistency and coordination in the governance and risk management of the financial sector with a view to minimising financial crime is not in doubt. Much as that is trite, this article has attempted to show how divergent the regulation of whistle-blowing is within selected countries and also demonstrates that the attainment of unified global standards is still work in progress. Whereas an analysis of the whistle blowing approach adopted in South Africa evinces a lot of weaknesses, the Swiss attitude to the disclosure of corporate malfeasance suggests that more could be done to build a supportive environment. These are issues that need to be given serious consideration especially in light of the lessons learned from the recent financial crisis.

Objectionable financial industry behavior characterized by exponential self-preservation and predatory governance could be curtailed if there was a real possibility of such conduct being made public through whistle blowing. As such the Swiss and South African financial sector should be encouraged to build trust by introducing suitable whistleblowing policies and procedures. Considering how globalized the financial sector has become, it is important that nations come up with harmonized frameworks that not only increase accountability of financial institutions and their supervisors but also restore trust in the financial sector and that address transnational governance problems. The first step to accomplishing that objective is by comparing the approaches in various regimes and this article has attempted to do that by comparing the Swiss and South African mechanisms and concludes that there is need for a shift in the current mechanisms.

\footnotetext{
${ }^{102}$ WVandekerckhove "European whistleblower protection: Tiers or tears?" in D Lewis (ed) A Global Approach to Public Interest Disclosure (2010, Cheltenham/Northampton MA, Edward Elgar) 15-35 at 20.
} 